ДЯГИЛЕВ Василий Васильевич - кандидат исторических наук, доцент; доцент департамента социологии, истории и философии Финансового университета при Правительстве РФ (125993, Россия, г. Москва, ГСП-3, Ленинградский пр-кт, 49; VVDyagilev@fa.ru)

ЗАМИРАЛОВА Татьяна Александровна - кандидат исторических наук, доцент кафедры истории, философии и социальных коммуникаций Омского государственного технического университета (644050, Россия, г. Омск, пр-кт Мира, 11; PVRazov@fa.ru)

\title{
МИФИЧЕСКИЕ ЦЕННОСТИ СОВРЕМЕННОГО МИРА: КУДА МЫ ИДЕМ?
}

Аннотация. В современном развивающемся обществе, в век технического прогресса мифы не утратили своей актуальности. Общество сталкивается с необходимостью духовного обоснования процессов и явлений современности. В статье поднимается проблема формирования ценностей и их переоценки в условиях глобализации; объясняется содержание понятий «миф" и “ценность», описывается сущность процессов мифологизации и ремифологизации; проводится мысль о связи ценностей с мифами и об их идеологическом и пропагандистском влиянии на процесс формирования ценностей. Авторы выдвигают идею о возвращении к культурным ценностям, способствующим этническому, народному, национальному развитию и приводят аргументы в пользу необходимости формирования государственной идеологии, которая могла бы привести к развитию и совершенствованию общества посредством переосмысления нравственных ценностей.

Ключевые слова: миф, мифологизация, ремифологизация, ценности, идеология, пропаганда, стимулирование потребления, явления современного мира, вызовы цивилизации, современное общество, культурное сближение, конфликтность в мировом социуме, деградация

Терроризм, трансвестивность и рак - возникают из-за перегрева политической, сексуальной и генетической игры и одновременно вызывают ослабление политического, сексуального и генетического кодов, обрекающего общество на деградацию. Ж. Бодрийяр

\footnotetext{
Сто лет назад О. Шпенглер писал, что мифы и представления о богах являются созданием первобытного человека, и то, что с прогрессирующей культурой души мифотворческая сила исчезает, есть научный предрассудок. Верно как раз обратное [Шпенглер 1998: 593]. Долгое время, особенно в отечественной философской и социологической литературе, миф трактовался просто как сказочный сюжет, как легенда или предание. Данная точка зрения имеет свое место и в толковых словарях, и в учебниках высшей школы. Но миф - это часть культурного генезиса, и, по-видимому, объяснять его как исторический феномен определенной удаленной от нас эпохи не представляется научно обоснованным взглядом. Мифы были и будут всегда. Они имманентно присущи человеческому роду. О том, что миф не является ни выдумкой, ни фикцией, писал замечательный русский философ А.Ф. Лосев: «Это заблуждение почти всех "научных" методов исследования мифологии должно быть отброшено в первую голову. Разумеется, мифология есть выдумка, если применить к ней точку зрения науки, да и то не всякой, но лишь той, которая характерна для узкого круга ученых новоевропейской истории последних двух-трех столетий» [Лосев 1991: 23].

Миф - это субъективное видение процессов и явлений действительности, которое в определенный исторический момент времени приобретает социальное значение.
} 
Мифы есть во всех сферах человеческой деятельности, человеческой практики. Они есть в религии, в искусстве и в науке. Но если о религиозном наполнении мифа говорилось достаточно много, то другие области мифотворчества часто остаются не зафиксированными в научной литературе. Даже мифы в сфере искусства не подвергались подробной систематизации и классификации (хотя миф о «Черном квадрате» К. Малевича уже сам оброс мифами). Еще менее исследована область научного мифотворчества. А она тоже весьма обширна. Мифы содержатся в школьных и вузовских учебниках, всплывают в научных публикациях, в самых авторитетных журналах. Некоторые мифы становятся даже научными теориями (например, дарвинизм - абсолютно метафизическое по своей сути учение). Парадоксально, но историческая наука в период кризисов сама становится одним из основных источников мифотворчества, пересматривая устоявшиеся истины и создавая новые, рассматривая своих idola theatri (идолы театра), о чем писал еще Ф. Бэкон [Бэкон 1971: 322].

В данной статье нам бы хотелось поговорить о мифах идеологических и пропагандистских. В период «переоценки», «переосмысления» ценностей, который начался в нашей стране после распада СССР, а на Западе, пожалуй, еще раньше, мифы проникают во все поры обшества, становятся базисной идеологической структурой. Данный процесс является следствием разочарования в «великих верованиях». В настоящее время мы можем видеть это на примере современной Украины. Попытки уничтожения прежних идеологических кумиров сопровождаются созиданием новых мифологических образов (Бандера, Шухевич). Данное явление вполне понятно и легко объяснимо для того чтобы дольше удержаться у власти, нынешней политической элите нужно активно вести борьбу «против» (при этом все равно, кто будет главным врагом, хотя, конечно, лучше, чтобы это был недруг главного спонсора). Такая «охота на ведьм», поддержанная средствами массовой информации и пропаганды, помогает сплотить массы вокруг ложных ценностей и отвлечь от реальных проблем. При этом миф может быть основой верований, базисом идеологии и пропаганды - как же может страта, стремящаяся к власти, пренебрегать мифами?

Но мифы нельзя оценивать односторонне, причем как с позитивной, так и негативной стороны. Древнегреческая мифология послужила основой для блестящего развития античной философии, способствовала формированию великих культурных ценностей. Но в то же время миф о неделимости атома, распространенный в научном сообществе в XX в., на несколько десятилетий задержал исследования в области сильного взаимодействия (можно вспомнить и теорию самозарождения жизни, господствовавшую в европейской науке в течение нескольких веков и опровергнутую Л. Пастером).

Миф, оказавший огромное влияние на современное общество и получивший свое распространение в конце прошлого века, - это миф об общечеловеческих ценностях. Данный миф основывается на сугубо превратных представлениях об общих значимостях, общих интересах и общих приоритетах в человеческой деятельности. Но каждая личность, сформировавшаяся в социуме, имеет свои неповторимые черты. Богатство общества, его перспективы зависят от существования как можно большего числа разносторонне развитых личностей. Но в последнем случае весьма затруднительно предположить, что у данных личностей будут идентичные ценности. Конечно, можно возразить, что такие ценности, как жизнь, здоровье, свобода, процветание, являются непреходящими. Но это не так. Террорист-смертник жертвует своей жизнью, совершенно не считаясь с жизнями других людей. Большинство наркоманов понимают, что в угоду удовольствию они жертвуют собственным здоровьем, при этом другие люди их 
вообще не интересуют - для них они только средство для возможного получения удовольствия.

С ценностным содержанием понятия «свобода» все обстоит еще сложнее. Существует большое число определений данного понятия. Свобода как возможность без ограничений воплощать в жизнь свои желания и стремления не имеет объективного смысла, т.к. человек ограничен внешне - социумом и внутренне - своими способностями, талантами, интеллектом. Свобода в своем формальном (юридическом) смысле, как возможность совершать все, что не запрещено законом, имеет большой социальный смысл. Но представление свободы в данном смысле нельзя назвать общечеловеческой ценностью, а лишь имеющей социальную значимость, но не индивидуальную. Крупные олигархи, представители политической элиты привыкли быть «над законом», и для них формальная свобода ценностью не является. Таким образом, мы приходим к тому, что либо «общечеловеческие ценности» будут приняты директивно, либо они вообще не будут иметь социального смысла. Но в первом случае мы имеем дело с разновидностью тоталитаризма, когда ценности попросту навязываются определенной части общества. При этом перечень «общечеловеческих ценностей» должен составляться определенным узким кругом профессиональных политических деятелей, чиновников или ученых. Конечно, можно говорить о вечных ценностях, таких как справедливость, любовь, дружба, долг и нравственность (перечень можно расширять и расширять). Но, к сожалению, в современном мире под видом вечных ценностей выступают спорные и далеко не однозначные предикаты, такие, например, как «толерантность», «феминизм», «осуждение гомофобии» и многое другое, подобное этому).

К тому же в реальности все обстоит еще хуже, чем в теории. Формированием ценностей занимаются средства массовой информации под прямым руководством транснациональных корпораций. В условиях глобализации, когда происходит процесс уничтожения этнических и религиозных ценностей, всеобъемлющее значение приобретает стремление получить прибыль. Следовательно, главной ценностью, которую будут пропагандировать ангажированные средства массовой информации, будет безудержное, всепоглощающее увеличение потребления, т.к. именно оно создает условия для капитализации предпринимательской деятельности, делает возможным получение не просто прибыли, а сверхприбыли.

В данных условиях стимулирование потребления должно быть мифологизировано и облагорожено. Потребление, не знающее границ, должно выглядеть как можно более привлекательно. Поэтому столь быстрыми шагами продвигается рекламная деятельность, разрастаются (качественно и количественно) $P R$-мероприятия.

В экономическом аспекте рост потребления имеет определенное позитивное значение, т.к. он стимулирует производство, приводит к улучшению уровня жизни в краткосрочной перспективе. Но в аксиологическом смысле рост потребления приводит к разрушению прежних смыслов, не привнося вообще ничего духовно значимого. Потребитель, лишенный духовных смыслов, в своей деятельности неизбежно обречен на деградацию. Но деградация личности неизбежно ведет и к деградации общества. «Заурядный человек боится как телесного напряжения, так еще больше и духовного; поэтому-то он невежествен, лишен мыслей и суждений», - писал А. Шопенгауэр [Шопенгауэр 2001: 55]. Именно поэтому кризис личностного развития может привести к социальным катаклизмам (к сожалению, сегодня это становится не только пугающе очевидным, но и фактически подтвержденным явлением).

Для того чтобы развиваться, человеку необходима духовная основа, в т.ч. и 
мифы - созидательные, зовущие к личностному совершенствованию. В то же время мифы, ориентированные на потребление, неизбежно вызовут у части социума конфликтные настроения и неизбежную деградацию. К тому же, т.к. нельзя удовлетворить запросы и потребности каждого, с течением времени будет возрастать дифференциация общества, и растущая конфликтность превратится в бескомпромиссное противоборство.

Так какое же будущее нас ждет? Возможен ли выход из данного «тупика безысходности»?

Такой выход представляется возможным, хотя и весьма затруднительным это возвращение к культурным ценностям, которые способствовали этническому, народному, национальному развитию. Необходимо формирование государственной идеологии, которая могла бы привести к социальному развитию и совершенствованию. Это возможно путем переосмысления нравственных ценностей. Необходимо возвращение к «почве», взрастившей нас. Так, Ф.М. Достоевский писал: «Заявлено вслух землей русской все, что чтит она и чему верует, указано ею то, что она считает “лучшим" и каких людей она почитает “лучшими”... В сущности, эти идеалы, эти “лучшие люди” ясны и видны с первого взгляда: “лучший человек” по представлению народному - это тот, который не преклонился перед материальным соблазном, тот, который ищет неустанно работы на дело божие, любит правду и, когда надо, встает служить ей, бросая дом и семью и жертвуя жизнью» [Достоевский 2011: 346].

Возрождение «народного духа» возможно лишь как мифологическое верование в правильность выбранного пути. Именно в данных условиях большую роль будут играть государственная идеология и перспективы социального развития. Это вещи взаимосвязанные и взаимообусловленные: без убежденности в правильности выбранного пути не будет и социального развития, но если развития нет, то не может быть и надежной уверенности в будущем. Надеяться на то, что все будет само собой регулироваться, не только наивно, но и пагубно. Вера в то, что сам по себе неизбежно наступит «золотой век», может привести только к социальной апатии, к уходу от реальной жизни, депривации. В недалеком прошлом подобная вера привела к убеждению, что сама жизнь, и только она, определяет ценностный мир человека. Результатом стала принявшая гипертрофированные масштабы манипуляция общественным и индивидуальным сознанием посредством пропагандистских клише, рекламы, воспитания конформистских настроений.

Современное общество как никогда живет стереотипами, при этом теряется своеобразие личностного мира, усредняются и унифицируются потребности. Таким обществом легко управлять, но такое общество обречено на деградацию и скорую гибель. То, что сегодня называют глобализацией, - это и есть программирование потребностей и устремлений индивида на данную «усредненность» (имеется в виду не информационная глобализация, имеющая объективное основание, а глобализация как идеологическое явление). Но можно ли в таком случае говорить о культурном сближении на национальном или народном уровне? Ни в коем случае. Пожалуй, сегодня все как раз наоборот. Конфликтность в мировом социуме уже сейчас приобрела катастрофические масштабы. Все чаще мы слышим о глобальных угрозах человечеству, и эти угрозы далеко не всегда связаны с природными явлениями. Все это наталкивает на мысль, что то, что называют глобализацией, не привело к сближению культур (цивилизаций), не сделало нас более толерантными, а привело к предельному оскудению ценностного мира человека (все более и более затягиваемого в обывательское болото).

Защищен ли современный человек, дал ли призыв к демократии и свободе свободу и демократию? И «свобода», и «демократия» давно стали мифами, 
понятиями, не имеющими определенного содержания: под данными лозунгами можно вмешиваться в дела других стран, в т.ч. и уничтожая их физически (Ливия, Ирак). Они трактуются так, как это выгодно тем, кто опирается на силу (политическую, экономическую, идеологическую). Мы трепетно относимся к свободе и демократии, зачастую совершенно не понимая смысла данных понятий. Им придается предельный ценностный смысл, а в содержательном аспекте этот смысл либо отсутствует, либо постоянно подменяется.

Ценности должны быть понятными, конкретными, они должны совпадать с психическими устремлениями личности. Ценности, пропагандируемые социумом, должны способствовать развитию отдельного индивида и общества в целом. Это могут быть только «вечные ценности», т.е. ценности, исторически обоснованные и рационально ясные. Глобальный мир должен быть подобен мозаичному панно, где каждая культура имеет свою специфику, создавая в целом законченную картину. Объективация истинных ценностей и разоблачение ложных - это ремифологизация, путь, который нам еще предстоит пройти.

\title{
Список литературы
}

Бэкон Ф. 1971. Сочинения в 2 томах. М.: Мысль. Т. 1.590 с. Достоевский Ф.М. 2011. Дневник писателя. М.: Эксмо. 736 с. Лосев А.Ф. 1991. Философия. Мифология. Культура. М.: Политиздат. 525 с. Шопенгауэр А. 2001. Собрание сочинений в 6 томах. М.: Терра. Т. 5.528 с. Шпенглер О. 1998. Закат Европы: в 2 т. М.: Мысль. Т. 1. 663 с.

DYAGILEV Vasiliy Vasil'evich, Cand.Sci. (Hist.), Associate Professor of the Department of Sociology, History and Philosophy, Financial University under the Government of the Russian Federation (49 Leningradsky Ave, GSP-3, Moscow, Russia, 125993;VVDyagilev@fa.ru)

ZAMIRALOVA Tat'yana Aleksandrovna, Cand.Sci. (Hist.), Associate Professor of the Chair of History, Philosophy and Social Communications, Omsk State Technical University (11 Mira Ave, Omsk, Russia, 644050; PVRazov@fa.ru)

\section{MYTHICAL VALUES OF THE MODERN WORLD: QUO VADIS?}

\begin{abstract}
In modern developing society, in the age of technical progress, myths have not lost their relevance. Society faces the need for spiritual substantiation of the processes and phenomena of modernity. The article raises the problem of formation of values and their revaluation in the context of globalization, and carries out the idea of the connection of values with myths and the ideological and propaganda influence on the process of value formation. The content of the concepts of myth and value is explained, the essence of the processes of mythologization and demythologization is described, and the ideological and propaganda influence on the process of forming values is shown. The authors put forward an idea of returning to cultural values conducive to ethnic, national, national development. The authors argue the need to form a state ideology, which could lead to the development and improvement of society through a rethinking of moral values.

Keywords: myth, mythologization, remifologization, values, ideology, propaganda, consumption stimulation, phenomena of modern world, challenges of civilization, modern society, cultural rapprochement, strife in world society, degradation
\end{abstract}

